\title{
FAKTOR-FAKTOR PENYELESAIAN DAN PENYELAMATAN PINJAMAN (KREDIT MACET) DI KOPERASI ARTHA SEJATI SEMARANG
}

\author{
Oleh \\ Angga Dwi Prabekti, Fitika Andraini
}

\begin{abstract}
ABSTRAK
Pinjaman sering terjadi dalam suatu perjanjian pinjaman (kredit), dimana merupakan suatu keadaan ketidak mampuan pihak debitur untuk membayar suatu kewajiban yang telah disepakati bersama oleh pihak kreditur sehingga kerugian pada pihak kreditur seperti yang terjadi pada KSP Artha Sejati Semarang. Adapun tujuan dari penelitian ini adalah untuk mengetahui dan memahami factor apa yang menjadi penyebab terjadinya pinjaman (kredit macet) serta upaya penyelesaian pinjaman (kredit macet) yang terjadi pada KSP Artha Sejati Semarang. Metode yang digunakan dalam penulisan ini adalah metode empiris yang menggunakan pendekatan dari aspek yang timbul dilapangan, yang memiliki sifat hukum yang nyata/ sesuai dengan kenyataan yang hidup dalam masyarakat.

Perumusan masalah yang diteliti dalam penulisan ini adalah Bagaimana tinjauan yuridis perjanjian pinjaman (kredit) di Koperasi Artha Sejati Semarang, Faktor- factor apa sajakah yang menyebabkan terjadinya pinjaman (kredit macet) pada Koperasi Artha Sejati Semarang, dan Bagaimana proses penyelamatan dan penyelesaian pinjaman (kerdit macet) pada Koperasi Artha sejati Semarang

Dari penelitian ini dapat menghasilkan factor eksternal yang menjadi penyebab pinjaman (kredit macet) adalah debitur mengalami hambatan/ kesulitan dalam kebutuhan ekonomi karena adanya suatu hal/ musibah sehingga menyebabkan terlambatnya pembayaran dalam melunasi angsuran. Sedangkanf aktor internal adalah lemahnya informasi dan pengawasan dalam perputaran kredit sehingga menyebabkan pengawasan menjadi tidak maksimal. Dan upaya yang dilakukan dalam penyelesaian kredit macet di KSP Artha Sejati Semarang adalah melalui penyelesaian diluar pengadilan/ non litigasi dan penyelesaian di dalam pengadilan, serta menyelamatkan aset-aset yang ada.
\end{abstract}

\section{Kata kunci:Perjanjian Pinjaman, Pinjaman, Koperasi, Pijaman}

Lending often occurs in a loan agreement (credit), which is a State party to the debtor's inability to pay an obligation that has been mutually agreed by the lender so that losses on the part of creditors as occur at the KSP Artha True Semarang. As for the purpose of this research is to know and understand what factors being the cause of the occurrence of loans (bad credit) as well as settling the loan (bad credit) happens on the KSP Artha True Semarang. The methods used in the writing of this is empirical method that uses an approach 
from the aspect arising in field, which has the nature of a real legal who live in thecommunity.

Formulation of the problem examined in this thesis is how writing reviews of juridical agreement loan (credit) in cooperative Artha True Semarang, what are the factors that led to the loan (kreditmacet) on Cooperative Artha True Semarang, and how the process of rescue and settlement of loans (kerdit jam) of the true Artha padaKoperasi Semarang Formulation of the problem examined in this thesis is how writing reviews of juridical agreement loan (credit) in cooperative Artha True Semarang, what are the factors that led to the loan (kreditmacet) on Cooperative Artha True Semarang, and how the process of rescue and settlement of loans (kerdit jam) of the true Artha on Cooperative Semarang

From this research can generate external factors which are the cause of loan (kerdit jam) is the debtor experienced barriers/difficulties in economic needs due to an accident causing late payment in pay off in installments. While the internal factor is the weak information and oversight in causing the credit turnaround supervision be not maximum. And the efforts made in the settlement of bad debts in the KSP Artha Semarang is True through the settlement outside the Court/non litigation and settlement in court, as well as save existing assets.

\section{Keywords: TheLoanAgreement, TheLoan, cooperatives, credit}

\section{Pendahuluan}

Perkembangan perekonomian diera globalisasi semakin meningkat, dengan banyaknya perputaran roda keuangan yang sekarang menjadi kebutuhan untuk memenuhi kehidupan setiap manusia. Semakin bertambahnya penduduk akan membuat manusia untuk semakin berjuang mendapatkan uang hasil kerja kerasnya, namun, apabila hasil kerja keras masih dianggap belum mampu untuk memenuhi kebutuhan hidup mereka, maka halnya pelaku ekonomi khususnya koperasi dianggap sebagai perusahaan yang bisa membantu untuk memberikan fasilitas simpan dan pinjaman (kredit) kepada masyarakat demi memenuhi kelangsungan hidup yang dianggap kurang
Sehubungan dengan hal itu, koperasi harus lebih tangguh dalam menghadapi perubahan dan persaingan yang terjadi didalam lingkungan koperasi itu sendiri atau bersaing dengan lembaga keuangan bukan bank lainnya, baik secara regional,maupun internasional. Koperasi merupakan bentuk badan usaha yang memiliki status sebagai badan hukum setelah akta pendiriannya disahkan oleh pemerintah, sesuai dengan ketentuan yang tercantum dalam ketentuan Pasal 9 Undang-Undang Nomor 25 Tahun 1992 tentang Perkoperasian. Pengertian koperasi menurut Undang-Undang No.25 Tahun 1992 adalah badan usaha yang beranggotakan orang-seorang atau badan hukum koperasi dengan berlandaskan kegiatannya berdasarkan prinsip koperasi 
sekaligus sebagai gerakan ekonomi rakyat yang berdasarkan atas asas kekeluargaan. Pada pasal 33 ayat (1) Undang-Undang Dasar 1945 menyebutkan perekonomian Indonesia disusun sebagai usaha bersama berdasarkan atas asas kekeluargaan dan koperasi adalah bangunan usaha yang sesuai dengan susunan perekonomian yang dimaksud dalam Undang-Undang Dasar 1945. ${ }^{1}$

Selain menjadi lembaga keuangan yang bertujuan memajukan kesejahteraan anggota pada khususnya dan masayarakat pada umumnya serta ikut membangun tatanan perekonomian nasional dalam rangka mewujudkan masyarakat yang maju, adil, dan makmur.untuk memberikan kredit dan jasa-jasa keuangan lainnya, peran koperasi sangatlah penting dalam menumbuhkan dan mengembangkan potensi ekonomi rakyat serta dalam mewujudkan kehidupan ekonomi yang demokratis, kekeluargaan, dan keterbukaan. $^{2}$

Oleh karena itu, bangsa Indonesia dianggap telah melakukan pembangunan untuk mewujudkan tujuan nasional, yaitu mewujudkan masyarakat yang adil dan makmur secara materiil dan spiritual berdasarkan Pancasila dan UndangUndang Dasar 1945.Koperasi dianggap juga menjadi urat nadi dalam perekonomian Indonesia, maka koperasi selalu bertindak

${ }^{1}$ Penjelasan Umum UU Koperasi No. 25

Tahun 1992 Tentang Perkoperasian

${ }^{2}$ Raharja Handikusuma, Hukum

Koperasi Indonesia, PT.Raja Grafindo, Jakarta 2000, hal 31 cenderung untuk melindungi mereka masyarakat yang ekonominya lemah yang menjadi anggota koperasinya.Secara umum koperasi dipahami sebagai perkumpulan orang yang secara sukarela mempersatukan diri untuk memperjungkan peningkatan kesejahteraaan ekonomi mereka pada suatu perusahaan yang demokratis.

Salah satu bidang usaha koperasi yang dirasakan kian hari semakin dibutuhkan masyarakat adalah masalah simpan pinjam (kredit) ${ }^{3}$.Koperasi simpan pinjam (kredit) ialah koperasi yang kegiatan atau jasa utamanya menyediakan jasa penyimpanan dan peminjaman (kredit) untuk anggotanya. Dengan demikian koperasi simpan pinjam (kredit) keseluruhan adalah sebuah lembaga keuangan yang bergerak yang bergerak di bidang simpan pinjam (kredit) yang dimiliki dan dikelola oleh anggotanya dan bertujutuan dan meningkatkan kesejahteraan anggotanya.

Salah satu koperasi simpan pinjam ( kredit) yang ada di Semarang adalah Koperasi Artha Sejati Semarang, dalam menggalakan usaha koperasi bertujuan untuk kesejahteraan anggota dalam melakukan kegiatan dibidang simpan pinjam (kredit). Koperasi Artha Sejati dalam kegiatan operasionalnya memberi jasa agar kesejahteraan anggota dapat terjamin dan mudah pemenuhan kebutuhan hidup anggotanya. Sesuai dengan sifat koperasi simpan pinjam, tujuan utama Koperasi Artha Sejati adalah untuk kesejahteraan anggota dalam

\footnotetext{
${ }^{3}$ Partadiredja Atje, Manajemen Koperasi, Penerbit Bhatara, Jakarta, 2000, hal 3
} 
melakukan kegiatan simpan pinjam(kredit). Selain itu Koperasi Artha Sejati juga berupaya menghindarkan para anggotanya dari rentenir yang memberikan pinjaman dengang bunga yang tinggi, tanpa perjanjian jelas yang dapat memperburuk keadaan perekonomian anggotanya.

Prinsip penilaian pinjaman pada koperasi Artha Sejati tertuang dalam Peraturan Menteri Negara Koperasi dan UKM Nomor :19/Per/M.KUKM/XI/2008 tentang pedoman pelaksanaan kegiatan usaha simpan pinjam koperasi dimana penilaian pinjaman(kredit) harus didasarkan pada prinsip kehati-hatian serta mempertimbangkan bahwa pemberian pinjaman(kredit) akan memberi manfaat bagi yang menerima dan diyakini pinjaman dapat dibayar kembali oleh peminjam sesuai dengan pinjaman.Semakin berkembangnya kegiatan koperasi dapat dilihat dari jumlah anggota koperasi tersebut dan seberapa banyak perputaran uang yang sudah memfasilitasi anggotanya tersebut.

Sehingga sudah sepantasnya koperasi yang berkembang harus selalu meningkatkan kemampuannya dalam mentransformasikan diri sesuai dengan perubahan-perubahan yang terjadi di Koperasi. Pinjaman(Kredit) macet sering terjadi dalam suatu perjanjian kredit, dimana merupakan suatu keadaan ketidak mampuan pihak debitur untuk membayar suatu kewajiban yang telah disepakati bersama oleh pihak kreditur sehingga kerugian pada pihak kreditur seperti yang terjadi pada KSP.Artha Sejati Semarang.

\section{Rumusan Masalah}

1. Bagaimana tinjauan yuridis perjanjian pinjaman (kredit) di Koperasi Artha SejatiSemarang ?

2. Faktor-faktor apa sajakah yang menyebabkan terjadinya pinjaman (kredit macet)pada Koperasi Artha Sejati Semarang ?

3. Bagaimana proses penyelamatan dan penyelesaian pinjaman (kerdit macet) pada Koperasi Artha sejati Semarang ?

\section{Tinjuan Pustaka}

\section{Tinjauan Umum}

\section{Pengertian Koperasi}

Kata Koperasi, memang bukan berasal dari khasanah bahasa Indonesia. Koperasi berasal dari bahasa Inggris co-operatioan, cooperative atau bahasa Latin coopere. Dalam bahasa Belanda cooperatie, cooperatieve, yang kurang lebih berarti bekerja bersamasama atau kerja sama atau yang bersifat kerja sama. Berikut pengertian koperasi menurut para ahli $\quad:^{4}$

Chaniago memberi definisi koperasi sebagai perkumpulan yang beranggotakan orang-orang atau badan hukum yang memberi kebebasan masuk dan keluar sebagai anggota dengan bekerja sama secara kekeluargaan menjalankan usaha untuk mensejahterakan anggotanya. . Wirjono Prodjodikoro dalam bukunya Hukum Perkumpulan Perseroan dan Koperasi Indonesia,

\footnotetext{
${ }^{4}$ Andjar Pachta W, Myra Rosana Bachtiar \&Nadia Maulisa Benemay, 2005, Hukum Koperasi Indonesia, Kencana predana media, Jakarta, hal.19
} 
mendefinisikan koperasi adalah bersifat suatu kerjasama antara orang-orang yang termasuk golongan kurang mampu, yang ingin bersamaan untuk meringankan beban hidup atau beban kerja.Mohammad Hatta dalam bukunya The Cooperative Movement in Indonesia, mengemukakan bahwa koperasi adalah usaha bersama untuk memperbaiki nasib kehidupan ekonomi berdasarkan tolongmenolong.

Sedangkan dalam UndangUndang Nomor 25 tahun 1992 tentang Perkoperasian memberikan definisi koperasi sebagai badan usaha yang beranggotakan orang-seorang atau badan hukum koperasi dengan melandaskan kegiatannya berdasarkan prinsip sekaligus sebagai gerakan ekonomi rakyat yang berdasarkan atas asas kekeluargaan.

Dengan definisi diatas, dapat dikatakan koperasi adalah perkumpulan orang perorangan secara sukarela yang bertujuan untuk memenuhi kebutuhan-kebutuhan, aspirasi ekonomi, sosial dan budaya bersama melalui perusahaan yang dimiliki bersama.

\section{Pengertian Perjanjian Pinjaman (Kredit)}

Pasal 1313 KUHPerdata mengawali ketentuan yang diatur dalam BabKedua Buku III KUH d. Perdata, dibawah judul "Tentang Perikatan-Perikatan yang dilahirkan dari Kontrak atau Perjanjian”, dengan menyatakan bahwa "Suatu perjanjian adalah suatu perbuatan dengan mana satu orang atau lebih mengikatkan dirinya terhadap satu orang atau lebih”.
Dari peristiwa ini, timbulah suatu hubungan antara dua orang tersebut yang dinamakan perikatan.Perjanjian itu menerbitkan suatu perikatan antara dua orang yang membuatnya.Dalam bentuknya, perjanjian itu berupa suatu rangkaian perkataan yang mengandung janjijanji atau kesanggupan yang diucapkan atau ditulis. Ketenruan dalam pasal 1313 KUH Perdata menjelaskan untuk terjadinya suatu perjanjian setidaknya harus ada dua pihak sebagai subyek hukum, dimana masing-masing pihak sepakat untuk mengikat dirinya dalam suatu hal tertentu yang berupa suatu perbuatan yang nyata, baik dalam bentuk ucapan, maupun tindakan secara fisik dan tidak hanya dalam bentuk pikiran semata-mata. ${ }^{5}$

Perjanjian kredit adalah perjanjian pokok (principal yang bersifat riil.Sebagai perjanjian prinsipil, maka perjanjian jaminan adalah assessor-nya.Ada dan berakhirnya perjanjian jaminan bergantung pada perjanjian pokok.Arti riil ialah bahwa terjanjinya perjanjian kredit ditentukan oleh penyerahan uang oleh bank kepada nasabah debitur. ${ }^{6}$ Salah satu dasar yang cukup jelas bagi lembaga keuangan mengenai keharusan adanya suatu perjanjian pinjaman (kredit).

Perjanjian pinjaman (kredit)koperasipada umumnya

\footnotetext{
${ }^{5}$ Kartini Muljadi \& Gunawan Widjaja, 2014, Perikatan Yang Lahir Dari Perjanjian, PT Raja Grafindo Persada, Jakarta, hal.8

${ }^{6}$ Hermansyah,SH.,M.Hum, 2009, Hukum koperasi Nasional Indonesia, Kencana, Jakarta, hal.71
} 
menggunakan bentuk perjanjian baku, dimana dalam perjanjian tersebut pihak debitur hanya dalam posisi menerima/menolak tanpa ada kemungkinan untuk melakukan negosiasi/tawar menawar. ${ }^{7}$ Dari pengertian diatas, dapat dikatakan perjanjian pinjaman (kredit) adalah suatu perjanjian yang dilakukan oleh pihak lembaga keuangan dengan menyerahkan uang kepada pihak debitur sesuai dengan isi perjanjian yang telah disepakati bersama

\section{Tinjauan Khusus}

\section{Pengertian Pinjaman ( Kredit )} Pinjaman ( Kredit ) berasal dari bahasa latin yaitu "credere" yang berati kepercayaan atau "credo" yang berati saya percaya ${ }^{8}$. Menurut Mac.Leod, kredit merupakan suatu reputasi yang dimiliki seseorang yang memungkinkan ia bisa memperoleh uang, barangbarang atau tenaga kerja, dengan jalan menukarkannya dengan suatu perjanjian untuk membayarnya disuatu waktu yang akan datang. Kreditur atau pihak yang memberikan kredit dalam hubungan perkreditan dengan debitur (nasabah penerima kredit) mempunyai kepercayaan bahwa debitur dalam waktu dan dengan syarat-syarat yang telah disetujui bersama dapat mengembalikan kredit yang bersangkutan. $^{9} \quad$ Pengertian kredit pada Undang-Undang Nomor 10

${ }^{7}$ Ibid, h.72

${ }^{8}$ Firdaus dan Ariyanti, pengertian Koperasi, Bandung, Tahun 2009 hal 1

${ }^{9}$ Hermansyah,, Hukum Koperasi

Nasional, Kencana, Jakarta,Tahun 2007 hal.60
Tahun 1998, kredit adalah penyediaan uang atau tagihan yang dapat dipersamakan dengan itu, berdasarkan persetujuan atau kesepakatan pinjam-meminjam antara bank dengan pihak lain yang mewajibkan pihak peminjam untuk melunasi utangnya setelah jangka waktu tertentu dengan jumlah bunga.

Tujuan dari kredit tersebut berupa untuk memenuhi kebutuhan hidup yang beraneka ragam sesuai dengan harkatnya, selalu meningkat.Sedangkan kemampuan manusia memiliki batasan tertentu, sehingga membuat seseorang untuk berusaha memperoleh bantuan permodalan untuk memenuhi kebutuhan hidup seseorang itu sendiri. Fungi kredit secara garis besar adalah pemenuhan jasa untuk melayani kebutuhan masyarakat dalam rangka mendorong dan melancarkan perdagangan, produksi, jasa-jasa, demi meningkatkan taraf hidup rakyat banyak.Dalam rangka menciptakan keseimbangan dan memelihara hak-hak yang dimiliki oleh para pihak sebelum perjanjian yang dibuat menjadi perikatan yang mengikat bagi para pihak, Kitab Undang-Undang Hukum Perdata memberikan asas umum yang merupakan pedoman atau patokan, serta menjadi batas dalam mengatur dan membentuk perjanjian yang akan dibuat hingga menjadi perikatan yang berlaku bagi para pihak, yang dapat dipaksakan pelaksanaannya.

\section{METODE PENELITIAN TIPE PENELITIAN}

Metode yang digunakan dalam penelitian ini adalah metode pendekatan Yuridis Normatif. Pada 
penelitian hokum jenis ini, sering kali hokum dikonsepkan sebagai apa yang tertulis dalam peraturan perundang-undangan (law in books) atau hukum yang dikonsepkan sebagai kaidah atau norma yang merupakan patokan berperilaku manusia yang dianggap pantas. Oleh karena itu, sumber datanya hanyalah data sekunder (bahan kepustakaan) ${ }^{10}$. Yang berkaitan dengan Faktor-faktor Penyelesaian dan Penyelamatan Pinjaman (Kredit Macet) Pada KSP Artha Sejati Semarang

\section{SPESIFIKASI PENELITIAN}

Spesifikasi dalam penelitian ini adalah deskriptif analitis, yaitu penelitian yang bertujuan mendeskripsikan mengenai Faktorfaktor Penyelesaian dan Penyelamatan Pinjaman (Kredit Macet) Pada KSP Artha Sejati Semarang, yang kemudian dikaitkan dengan teori-teori hokum dan praktek pelaksanaan hokum positif yang menyangkut permasalahan diatas.

\section{SUMBER DATA}

Sumber data dalam penelitian ini adalah menggunakan data sekunder (kepustakaan) dimana dalam data sekunder terdiri dari bahan hukum primer, bahan hokum sekunderdan data tersier, yaitu sebagai berikut ${ }^{11}$ :

1) Bahan Hukum Primer, yaitu bahan-bahan hukum yang mengikat, yang terdiri dari:

a. Undang-Undang Dasar Republik Indonesia 1945

\footnotetext{
${ }^{10}$ Amiruddin, PengantarMetodePenelitianHukum, Jakarta : Raja GrafindoPersada, 2013, Hal 118

${ }^{11}$ Ibid, 119
}

b. Kitab Undang-Undang Hukum Perdata

c. Undang-Undang RI No. 25 Tahun 1992 tentang Perkoperasian d. Peraturan perundangan lainnya yang berkaitan dengan materi penulisan hukum ini.

2). BahanHukumSekunder, yaitu bahan yang memberikan penjelasan mengenai bahan hukum primer, seperti rancangan hokumUndangUndang, atau pun buku- buku hasil penelitian yaitu buku dari :

a. Buku-buku atau hasil penelitian yang membahas tentang penyelesaian pinjaman bermasalah pada koperasi

b. Majalah-majalah dan dokumen- dokumen yang berkaitan dengan masalah penyelesaian pinjaman bermasalah pada koperasi

\section{METODE PENGUMPULAN DATA}

Data yang diperlukan dalam penelitian ini adalah :

1. Data primer

Data primer, yaitu data yang diperoleh secara langsung dari sumber aslinya melalui salah satu upaya wawancara langsung dengan sumberatau responden yang bersangkutan yaitu dari studi lapangan, yang dilakukan dengan cara : interview dan questioner (pertanyaan), pengamatan langsung dan bahan hukum.

2. Data sekunder

Data sekunder adalah data yang diperoleh dari buku atau literature melalui studi kepustakaan, yaitu berupa karangan para ahli yang mengupas tentang Pinjaman (kredit macet) dan bahan bahan kuliah untuk mendapatkan pengetahuan teoritis di 
dalam penyusunan penulisan skripsi ini.

\section{METODE PENYAJIAN DATA}

Bahan data yang diperoleh disajikan dalam bentuk uraian yang disusun secara sistematis dan logis. Yang dimaksud sistematis adalah keseluruhan data sekunder yang diperoleh akan dihubungkan satudengan yang lainnya, disesuaikan dengan pokok permasalahan yang diteliti sehingga merupakan kesatuan yang utuh.

\section{METODE ANALISIS DATA}

Analisis yang dipergunakan dalam penulisan skripsi ini adalah deskriptif analisis, yaitu suatu metode analisis yang dilakukan dengan cara mengumpulkan semua bahan yang diperoleh untuk kemudian ditelaah dan dianalisis berdasarkan peraturan perundang-undangan dan teori yang berkaitan dengan permasalahan yang akan dibahas. Selanjutnya mengambil kesimpulan dengan menggunakan metode deduktif yaitu proses penarikan kesimpulan yang dimulai dari hal-hal yang bersifat umum menuju hal-hal yang bersifat khusus. Analisis data secara sistematis dilakukan dengan tiga langkah secara bersamaanyaitu :

Pertama, reduksi data diartikan sebagai proses pemilihan, pemusatan perhatian pada penyederhanaan data, pengabstrakan dari informasi data besar yang muncul dari catatancatatan tertulis dilapangan.

Kedua, penyajian data, yakni penyajian sekumpulan informasi sistematis yang memberi kemungkinan adanya penarikan kesimpulan dan pengambilan tindakan. Penyajian tersebuat dapat berupa table dan bagan

Ketiga, penarikan kesimpulan atau verifikasi. Langkah verifikasi dilakukan sejak permulaan, pengumpulan data, dan alur sebab akibat.

\section{Hasil Penelitian dan Analisa Data Faktor-Faktor Penyelamatan dan Penyelesaian Pinjaman (kredit macet) di Koperasi Artha Sejati}

Berdasarkan hasil penelitian yang diperoleh mengenai pelaksanaan pengawasan pinjaman, pada Koperasi Artha Sejati Semarang telah memenuhi aspek -aspek berdasarkan peraturan-peraturan serta teori-teori yang berlaku. Berikut merupakan aspek-aspek penilaian dari kegiatan pengawasan pinjaman dari Koperasi Artha Sejati Semarang $:^{12}$

1. Pengawasan syarat-syarat pemberian persyaratan umum pengajuan pinjaman

Seperti yang telah dijelaskan sebelumnya masyarakat yang ingin melakukan pinjaman kepada Koperasi Artha Sejati Semarang harus terlebih dahulu menjadi anggota koperasi ini.Hal ini sudah mencerminkan salah satu standar operasional koperasi berdasarkan Undang-undang Perkoperasian tahu

\footnotetext{
${ }^{12}$ Wawancara dengan bapak fendi, selaku Manager Koperasi Artha

Sejati Semarang pada tanggal
}

13agusus 2018 
2012.Selain itu, anggota harus melengkapi persyaratan seperti KTP, jaminan (BPKB/SHM), kartu keluarga dan persyaratan lainnya yang merupakan persyaratan dasar dalam pengajuan pinjaman berdasarkan teori perpinjaman. Kekurangan dari persyaratan pemberian pinjaman pada Koperasi Artha Sejati Semarang terletak pada ditiadakannya pencantuman laporan keuangan dari suatu perusahaan anggota yang melakukan pinjaman. Tanpa adanya laporan keuangan ini dapat memperbesar risiko pinjaman bermasalah dari pinjaman yang akan disalurkan.

Berdasarkan ketentuan diatas diatur dalam perjanjian pinjaman (kredit) antara peminjam dengan Koperasi Artha Sejati Semarang yang diwakili oleh Manager, sudah sesuai dengan undang-undang yang berlaku yaitu diatur dalam pasal 1320 KUH Perdata.

a. kecakapan untuk membuat suatu perikatan;

Kesepakatan merupakan keadaan dimana terjadinya kesepakatan secara bebas dintara para pihak yang mengadakan/melangsungkan

perjanjian. Dalam perjanjian, kesepakatan merupakan perwujudan dari kehendak dua atau lebih pihak dalam perjanjian mengenai apa yang mereka kehendaki untuk dilaksanakan, bagaimana cara melaksanakannya, kapan harus dilaksanakan, dan siapa yang harus melaksanakan.Dan diatur dalam perjanjian pinjaman (kredit)

1) Penentuan jumlah plafond maksimum pinjaman

Penetapan plafond pinjaman pada suatu koperasi harus sesuai denagn peraturan yang telah
ditetapkan.Koperasi Artha Sejati

Semarang seperti yang telah dijelaskan, yaitu pinjaman produktif yang menggunakan agunan yang dapat ditetapkan maksimal 35\% dari nilai agunan.Penetapan tersebut ditentukan berdasarkan SOP koperasi simpan pinjam yang diterbitkan Kementerian UMKM pada tahun 2008.

Berdasarkan ketentuan diatas diatur dalam perjanjian pinjaman (kredit) diatur pasal 1 dan 2 antara peminjam dengan Koperasi Artha Sejati Semarang, sudah sesuai dengan undang-undang yang berlaku yaitu diatur dalam pasal 1320 KUH Perdata.

b. Suatu pokok persoalan tertentu

kitab Undang-Undang Hukum Perdata menjelaskan maksud hal tertentu, dengan memberikan rumusan dalam Pasal 1333 yang berbunyi sebagai berikut:

Suatu perjanjian harus mempunyai pokok berupa suatu barang yang sekurang-kurangnya ditentukan jenisnya. Jumlah barang itu tak perlu pasti, asal saja jumlah itu kemudian dapat ditentukan atau dihitung

2) Penentuan agunan pinjaman

Koperasi Artha Sejati Semarang mengharuskan agunan yang digunakan untuk pengajuan pinjaman harus milik pribadi dari anggota yang melakukan pinjaman. Oleh karena itu dalam proses pengajuan pinjaman, anggota harus menyertakan surat bukti kepemilikan agunan serta agunannya (khusus kendaraan bermotor) untuk dicocokkan keasliannya.

Berdasarkan ketentuan diatas diatur dalam perjanjian pinjaman (kredit) diatur pasal 15 antara peminjam 
dengan Koperasi Artha Sejati Semarang, sudah sesuai dengan undang-undang yang berlaku yaitu diatur dalam pasal 1320 KUH Perdata

c. Suatu sebab yang terlarang Suatu sebab yang halal dimaksudkan yaitu apa yang diperjanjikan itu harus bebas dari unsur-unsur yang dianggap tidak benar bila dipandang menurut hukum, agama maupun norma-norma lainnya. Sebab yang halal diatur dalam Pasal 1335 hingga Pasal 1337 KUHPerdata.Pasal 1335 KUHPerdata menyatakan bahwa "suatu perjanjian tanpa sebab atau yang telah dibuat karena suatu sebab yang palsu atau yang terlarang, tidaklah mempunyai kekuatan. Pasal 1336 KUHPerdata menyatakan bahwa jika tidak dinyatakan suatu sebab, tetapi ada sebab yang tidak terlarang, atau jika ada sebab lain selain daripada yang dinyatakan, perjanjian itu adalah sah. Pasal 1337 KUHPerdata menyatakan bahwa suatu sebab adalah terlarang, apabila dilarang oleh undang-undang atau apabila berlawanan dengan kesusilaan baik atau ketertiban umum.

a) Pengawasan Intern Perpinjaman Koperasi Artha Sejati Semarang

Pengawasan intern perpinjaman pada Koperasi Artha Sejati Semarang bertujuan untuk meminimalisir adanya kemungkinan pelanggaran oleh pihak intern Koperasi Artha Sejati Semarang dalam proses penyaluran pinjaman. Koperasi Artha Sejati Semarang dalam proses penyaluran pinjaman telah menggunakan software yang mempermudah pengendalian intern. Seperti yang telah dibahas sebelumnya, untuk memperoleh keputusan pelepasan pinjaman harus melalui prosedur dari beberapa pihak.Penyimpangan penyaluran pinjaman pada Koperasi Artha Sejati Semarang dinilai sulit kecuali adanya kerjasama antar pihak intern pada Koperasi Artha Sejati.

b) Survei On The Spot

Koperasi Artha Sejati Semarang hanya menerapkan survey on the spot kepada anggota yang baru pertama kali melakukan pinjaman.Sedangkan bagi anggota lama yang melakukan pinjaman untuk yang kesekian kali tidak diberlakukan survey on the spot. Pihak Koperasi Artha Sejati Semarang hanya melakukan analisis pinjaman dari dokumen-dokumen terdahulu dari anggota yang bersangkutan.Hal ini dapat memperbesar risiko pinjaman bermasalah, karena keakuratan data lama yang tidak sesuai dengan keadaan actual dari anggota yang melakukan pinjaman tersebut.

c) Pengawasan Terhadap Anggota

Koperasi Artha Sejati Semarang mengutamakan kepercayaan dan penyelesaian masalah berdasarkan kekeluargaan (pengawasan pasif) dalam pengawasan terhadap anggotanya.Hal ini memang sudah sesuai dengan asas kekeluargaan yang dianut koperasi di Indonesia.Namun hal ini dinilai berisiko karena kurangnya pengawasan aktif yang dilakukan Koperasi Artha Sejati Semarang.

d) Asuransi Pinjaman

Hal positif lain yang dimiliki Koperasi Artha Sejati Semarang dalam pengawasan pinjaman adalah kerjasamanya dengan perusahaan asuransi. Kerjasama tersebut berupa 
pemberian asuransi terhadap suratsurat berharga dari agunan yang diterima Koperasi Artha Sejati Semarang.Asuransi ini bertujuan untuk melindungi surat-surat berharga dari risiko yang tidak diinginkan seperti kebakaran atau bencana alam.Sehingga dengan adanya asuransi tersebut, dinilai memberi rasa aman dan percaya dari pihak anggota atas surat-surat berharga yang dititipkan kepada Koperasi Artha Sejati Semarang.

Dalam pelaksanaan pinjaman pada Koperasi Artha Sejati Semarang dilakukan melalui langkah-langkah yang sangat membantu anggota koperasi serta dapat mengatasi masalah yang timbul bagi pengurus Koperasi Artha Sejati Semarang dalam menyetujui atau tidak permohonan pinjaman tersebut. Sedangkan yang menjadi ketentuan atau pertimbangan dalam pelaksanaan pinjaman tersebut berdasarkan besar simpanan anggota koperasi dan besarnya gaji atau penghasilan anggota yang akan melakukan pinjaman tersebut. Hanya saja dalam melaksanakan pinjaman tersebut kadang tidak sesuai dengan aturan yang ada seperti pemberian pinjaman akan diberikan apabila anggota telah melunasi pinjamannya, pemberian pinjaman diberikan kepada anggota yang masih memiliki pinjaman yang belum selesai dilunasi, hal ini karena pengurus koperasi melihat secara subyektif kepada anggota yang mengajukan pinjaman dan manggunak asas kekeluargaan dalam pelaksanaan pinjaman tersebut sehingga kurang tegas dalam menjalankan prosedur yang telah ada.
Menurut Munir fuady, "Sebagaimana diketahui bahwa menurut sistem hokum manapun di ddunia ini, kesepakatan kehendak merupakan salah satu syarat sahnya suatu kontrak, seperti misalnya ditentukan dalam Pasal 1320 KUH perdata”.

Koperasi Artha Sejati Semarang mempunyai pertimbangan tertentu dalam memberikan pinjaman kepada anggota koperasi. Koperasi artha sejati semarang umumnya berfikir dan bertindak dalam memberikan pinjaman setelah menilai persyaratan $5 \mathrm{C}$ yang dimiliki calon anggota, yakni collaterals, capitals, capacities, cacarcters dan conditions of economics. Seorang calon peminjam (anggota koperasi) dikabulkan permohonannya apabila mempunyai jaminan atau agunan (collateral) yang melebihi jumlah pinjaman. Jumlah uanga pinjaman yang diberikan tidak akan melebihi 70\% dari nilai agunan. Pada saat uang pinjaman didapatkananggota koperasi harus menyerahkan bukti kepemilikan agunan tersebut kepada Koperasi Artha Sejati Semarang. Bila terjadi kemacetan dalam pengembalian utang, agunan tersebut dijadikan Koperasi Artha Sejati Semarang sebagai pembayaran atas utang yang tertunggak atau agunan itu akan dijual kepada pihak ketiga untuk melunasinya.

Koperasi Artha Sejati Semarang akan memberikan pinjaman kepada calon anggota koperasi yang memiliki modal (capital)walaupun hanya sedikit dan bukan kepada anggota koperasi yang tidak mempunyai modal sama sekali. Pinjaman yang diberikan Koperasi berfungsi sebagai tambahan modal untuk 
memperlancar kegiatan produktif sehingga kegiatan tersebut semakin efektif dan efesien. Anggota koperasi harus memiliki sejumlah dana yang dialokasikan secara khusus sebagai modal awal bagi kegiatan produktif tersebut. Kemampuan (capacities) anggota koperasi dalam memanfaatkan dan mengembalikan pinjaman akan dinilai Koperasi yang akan memberikan pinjaman. Koperasi Artha Sejati Semarang menilai kemampuan calon anggota koperasi dengan menganalisis kelayakan proposal yang anggota koperasi buat sewaktu mengajukan permohonan.Bila anggota koperasi mengajukan pinjaman untuk usaha, kemampuan anggota koperasi juga dinilai dari perjalanan usaha yang telah anggota koperasi lakukan selama ini berdasarkan laporan keuangan yang anggota koperasi miliki.

Koperasi Artha Sejati Semarang juga akan menilai sifatsifat (characters) anggota koperasi dalam mengelola uang, terutama kejujuran, kedisiplinan dan kebiasaan dalam mengatur cash flow. Buku tabungan atau rekening Koran yang anggota koperasi miliki menjadi sumber informasi bagi Koperasi Artha Sejati Semarang dalam menilai sifat-sifat anggota koperasi dalam mengelola uang.Pertimbangan Koperasi Artha Sejati Semarang terhadap kondisi ekonomi (conditions of economics) yang sedang dihadapi.Kondisi ekonomi yang baik menyebabkan koperasi member banyak kemudahan dalam memberikan pinjaman.Sebaliknya kondisi ekonomi yang sedang sulit mengakibatkan Koperasi Artha Sejati Semarang agak ketat dalam memberikan pinjaman kepada para anggota koperasi.

\section{Faktor-Faktor Yang Menyebab kan Pinjaman Bermasalah Pada Koperasi Artha Sejati Semarang}

Banyak sekali kenyataan di lapangan yang mengungkapkan bahwa sumber daya manusia yang ikut terlibat didalamnya baik sebagai anggota, pengurus, maupan pengelola koperasi kurang bias mendukung jalannya koperasi. Dengan kondisi seperti ini maka koperasi berjalan dengan tidak professional dalam arti tidak dijalankan sesuai dengan kaidah sebagaimana dalam usaha lainnya.

Adanya pinjaman bermasalah walaupun presentasenya sangat kecil karena terdapat anggota yang masih mempunyai pinjaman tetapi sudah meminjam kembali sehingga adanya pinjaman ganda yang dapat mebebratkan peminjam dalam membayar. Selain itu dalam prosedur pencairan dana dalam jumlah besar biasanya mengalami keterlambatan sebab pengurus koperasi harus menunggu sampai dana kas tercukupi untuk memenuhi pinjaman tersebut, padahal jika sesuai prosedur seharusnya apabila dana belum mencukupi, pengurus seharusnya tidak memberikan persetujuan pinjaman sehingga mengakibatkan pemohon pinjaman harus menunggu lama dalam pencairan dana tersebut, akan tetapi pinjaman bermasalah yang terjadi dapat diatasi pada akhir tahun oleh pengurus Koperasi, karena anggota/calon anggota yang mempunyai pinjaman bermasalah selalu melunasi hutangnya, sebelum 
melakukan pinjaman lagi pada Koperasi.

Pihak pengurus Koperasi Artha Sejati Semarang mencoba menyelesaikan masalah pelaksanaan peminjaman yang kurang lancer dengan cara melakukan pemotongan langsung dari dana simpanan wajib anggota yang rutin dibayarkan anggota setiap bulan, bagi anggota yang tidak dapat membayar angsuran peminjamannya sehingga anggota tersebut dapat menyelsaikan tunggakannya dan koperasi dapat memutarkan kembali modal untuk a. dipinjamkan kepada anggota yang lain.

Berdasarkan faktor-faktor diatas b. adanya Wanprestasi perjanjian pinjaman (kredit) pasal 9 sampai 11dan dalam KUH Perdata Pasal 1243 KUH Perdata yang berbunyi :

Penggantian biaya, rugi, dan c. bunga karena tidak dipenuhinya suatu perikatan, barulah mulai diwajibkan apabila debitur setelah dinyatakan lalai memenuhi perikatannya, tetap melalaikannya, atau jika sesuatu yang harus diberikan atau dibuatnya dalam tenggang waktu tertentu telah dilampauinya.Maksud dari berada e. dalam keadaan lalai ialah peringatan atau pernyataan dari kreditur tentang saat selambat-lambatnya debitur wajib memenuhi prestasi.Apabila saat ini dilampauinya, maka debitur ingkar janji (wanprestasi). Jika salah satu pihak tidak memenuhi prestasinya maka dinyatakan sebagai wanprestasi. Wujud dari wanprestasi atau tidak memenuhi perikatan ada 4 (empat) macam, yaitu ${ }^{13}$ :

\footnotetext{
${ }^{13}$ Subekti, Aneka Perjanjian, Alumni , Bandung, 2003, hal 45
}

1 Debitur sama sekali tidak memenuhi perikatan,

2 Debitur terlambat memenuhi perikatan,

3 Debitur keliru atau tidak pantas memenuhi perikatan.

4 Debitur melakukan sesuatu yang oleh perjanjian tidak boleh dilakukan.

Akibat hukum bagi debitur yang telah melakukan wanprestasi adalah hukuman atau sanksi yang di atur oleh KUHPer sebagai berikut :

Debitur diwajibkan membayar ganti kerugian yang telah diderita oleh kreditur (Pasal 1243 KUH Perdata), Apabila perikatan itu timbal balik, kreditur dapat menuntut pemutusan/pembatalan perikatan melalui Hakim (Pasal 1266 KUH Perdata),

Dalam perikatan untuk memberikan sesuatu, resiko beralih kepada debitur sejak terjadi wanprestasi (Pasal 1237 ayat 2 KUH Perdata),

Debitur diwajibkan memenuhi perikatan jika masih dapat dilakukan, atau pembatalan disertai pembayaran ganti kerugian (Pasal 1267 KUH Perdata),

Debitur wajib membayar biaya perkara jika diperkarakan di muka Pengadilan Negeri, dan debitur dinyatakan bersalah (Abdulkadir, 2000: 204-205).

Upaya Penyelesaian dan Penye lamatan Terhadap Pinjaman (Kredit macet) Koperasi Artha Sejati Semarang

Berdasarkan hasil analisis yang telah dilakukan, terdapat beberapa tahapan yang dilakukan dalam upaya penyelesaian terhadap pinjaman 
bermasalah pada Koperasi Artha Sejati Semarang, yaitu :

Mengidentifikasi

permasalahan, mengumpulkan informasi-informasi actual tentang anggota/calon anggota, termasuk menghubungi anggota bermasalah yang berada di luar kota, karena anggota Koperasi Artha Sejati Semarang keberadaannya sudah tersebar di luar Kota Semarang.

2) Mengklasifikasi permasalahan, apabila dalam hal komunikasi dengan anggota/calon anggota tidak dapat kata sepakat untuk menyelasaikan, maka Koperasi Artha Sejati Semarang akan mengeluarkan Surat Peringatan I,II,III.

3) Penyusunan dan pengalihan strategi penyelamatan beupa penjadwalan kembali yaitu dapat berupa perpanjangan waktu pinjaman, persyaratan dan penataan kembali yaitu dapat berupa penambahan agunan, reorganisasi dan rekapitulasi 1 yaitu salah satunya dapat berupa penurunan suku bunga, penambahan pinjaman agar usaha dapat berjalan kembali.

4) Penjualan

asset/agunan dalam hal ini Koperasi Artha Sejati Semarang mencoba menawarkan kepada anggota/calon anggota yang bermasalah untuk menjual sendiri agunannya untuk kemudian diperhitungkan hasil penjualan sengan kewajiban yang harus dibayarkan kepada Koperasi, atau dapat juga pihak Koperasi melakukan penjualan sendiri hal ini dapat dilakukan karena anggota/calon anggota kurangdapat berkomunikasi/ bermusyawarah dengan baik.

5) Penyegelan, apabila sudah tidak dapat dicapai kata sepakat maka Koperasi Artha Sejati Semarang melakukan penyegelan terhadap agunan dengan menempel stiker pada benda agunan tersebut.

6)

SHU/Sisa Hasil Usaha uamg seharusnya terbagikan kepada anggota dalam hal ini akan ditahan/ditunda dahulu untuk kepentingan cadangan resiko.

7)

Koperasi Artha Sejati Semarang berusaha agar pinjaman bermasalah tidak mengganggu operasional pinjamannya agar tetap sehat dengan cara menghapus buku atas pinjaman bermasalah namun tidak hapus tagih jadi tetap dilakukan pengalihan atau collection atas pinjaman tak terbayar tersebut.

\section{Kesimpulan}

Tinjauan yuridis perjanjian pinjaman (kredit) di Koperasi Artha SejatiSemarang harus melalui tahaptahap perjanjian tertulis yang kegiatan pelaksanaan yang dilakukan Koperasi Artha Sejati Semarang mulai dari proses permohonan pinjaman dari pihak koperasi mengajukan analis/survei setelah itu dirapatkan komite berdasarkan keputusan apakah pinjaman di setujui atau tidak akan pencairan dana atau pra realisasi hingga pelunasan anggota atau pasca realisasi. Pelaksanaan pinjaman ini bermuara pada pengawasan pinjaman, yaitu meminimalisir terjadinya risiko kerugian dari adanya fasilitas pinjaman kepada anggota koperasi.

Alur perjanjian pinjaman 
1. Anggota/Calon Mengajukan permohonan

2. Survey analisis Prinsip $5 \mathrm{C}$ dan $7 \mathrm{P}$ Rapat

3. Panitia Pinjaman / Komite

4. Keputusan Rapat / Komite

5. Pencairan Dana

2. Factor-faktor yang menyebabkan pinjaman bermasalah pada Koperasi Artha Sejati Semarang, yaitu (1) faktor internal meliputi sumber daya manusia (sdm) kurang profesional, memotong rantai komite, kurang mengidahkan prinsip-prinsip $5 \mathrm{C}$ dan \& $\mathrm{P}$, manajemen kurang terorganisir dengan baik dan profesional. (2) faktor eksternal yaitu adanya itikad yang kurang baik dari anggota, memburuknya kondisi bisnis anggota /calon anggota/peminjam

Upaya penyelesaian terhadap pinjaman bermasalah pada Koperasi Artha Sejati Semarang antara lain : penjadwalan kembali (rescheduling), persyaratan (reconditioning) dan penataan kembali (restructuring), reorganisasi dan rekapitulasi (reorganization and recapitulation), 4. pembinaan anggota, peringatan berupa penempelan plang/stiker pada agunan

\section{Saran}

Agar Koperasi Artha Sejati Semarang di tahun-tahun yang akan dating lebih maju dan dapat menghindari resiko/meminimalis resiko maka saran penulis adalah:

1. Meningkatkan kemampuan dan 5 . pengetahuan serta kualitas sumber daya manusia yang dimiliki oleh Koperasi dalam menganalisis pinjaman senantiasa harus selalu diupayakan, ini dimaksudkan

untuk mengimbangi perkembangan dan tuntutan pasa yang makin berkembang.

2. Mengupayakan agar Rasio Kualitas Aktiva Produktif (KAP) yang saat ini dalam kondisi kurang sehat yaitu 25,96\% agar dapat mencapai criteria minimal cukup sehat.

3. Hendaknya pihak Koperasi Artha Sejati Semarang dalam menetapkan nilai jaminan lebih memperhitungkan secara cermat sehingga apabila seorang anggota koperasi melakukan tunggakan oembayaran dalam waktu lama, nilai jaminan tersebut tetap dapat menutup hutang pokok dan biaya-biaya atas keterlambatan tersebut.

3. Diupayakan untuk memasang jaminan dengan pengikatan sempurna/notaril sehingga apabila anggota/calon anggota bermasalah maka Koperasi Artha Sejati Semarang mempunyai kekuatan untuk melakukan eksekusi lewat jalur pengadilan.

Agar pengelola lebih berinovatif dalam mengembangkan produk-produk baru, bekerjasama dengan instansi-instansi lain yang saling menguntungkan, serta dapat memberikan sayap Koperasi Artha Sejati Semarang tidak hanya di Kota Semarang tapi mempunyai jangkauan lebih luas yaitu dapat membuka cabang sampai tingkat nasional

\section{Daftar Pustaka}

Amiruddin, 2013, PengantarMetodePenelitian $\mathrm{Hu}$ kum, Raja GrafindoPersada, Jakarta. 
Dr Ahmad Subagyo, 2014, Manajemen Koperasi Simpan Pinjam, Mitra Wacana Media, Jakarta.

Kartini Muljadi \& Gunawan Widjaja, 2014, Perikatan Yang Lahir Dari Perjanjian, PT Raja Grafindo Persada, Jakarta.

Prof. R. Subekti, 2013, Hukum Perjanjian, Citra Aditya Bhakti, Jakarta.

R.Daeng Naja, 2005, Hukum Pinjaman, Citra Aditya Bakti, Jakarta.

Raharja Handikusuma, 2000, Hukum Koperasi Indonesia, PT.Raja Grafindo, Jakarta.

Suyanto dan Nurhadi, 2008, Akuntasi untuk Koperasi dan UKM, Salemba Empat, Jakarta.
Firdaus dan Ariyanti, pengertian Koperasi, Bandung, Tahun 2009.

Hermansyah,SH.,M.Hum, 2009, Hukum Koperasi Nasional Indonesia, Kencana, Jakarta. Raharja Handikusuma, 2000, Hukum Koperasi Indonesia, PT.Raja Grafindo, Jakarta.

\section{Perundang-Undangan}

Kitab Undang-Undang Hukum Perdata

Undang-Undang No.25 Tahun 1992 tentang Perkoperasian

Pp tentang koperasi tahun 1995 www.smecda.com/Files/infosmecda/ misc/Koperasi Iskandar.pdf

http://www.depkop.go.id tentang Pedoman Standar Operasional Koperasi Simpan Pinjam dan nit Koperasi Simpan Pinjam 